\title{
Ortaokul Öğrencilerinin Bilgisayar Oyun Bağımlılığı Düzeyleri ile Sorumluluk Davranışı Arasındaki ilişki
}

\section{Relationship Between Computer Game Addictions Levels and Responsibility Behaviour of Secondary School Students}

\section{Beste DiNÇER ${ }^{1}$, Halil ibrahim KOLAN ${ }^{2}$}

\author{
Anahtar Kelimeler \\ Bilgisayar oyun \\ bağımlılığ \\ Ortaokul öğrencileri \\ Sorumluluk
}

\section{Keywords}

Computer game

addiction

Secondary school

students

Responsibility

Başvuru Tarihi/Received

17.11.2019

Kabul Tarihi /Accepted

16.11.2020
Öz

Oyun, çocuğun hayatı keşfettiği, akranlarıyla sosyal ortama katıldığı, yetenek ve bilgilerini yapılandırdığı bir faaliyettir. Geçmişte daha çok sokakta veya doğal ortamda oynanan oyunlar artık çevrimiçi ortamda oynanmaya başlamıştır. Bu çalışma ortaokul öğrencilerinin bilgisayar oyun bağımlılığı düzeylerinin cinsiyet, sınıf düzeyi, ailenin gelir düzeyi, kişisel bilgisayara sahip olma değişkenlerine göre anlamlı farklılık gösterip göstermediğini ve bilgisayar oyun bağımlılığı ile sorumluluk davranışı arasındaki ilişkiyi incelemek amacıyla yapılmıştır. Çalışmanın örneklemini Aydın il merkezindeki beş devlet ortaokulunda öğrenim gören 7. ve 8. sınıf öğrencileri arasından basit seçkisiz örnekleme yöntemiyle seçilen gönüllü 352 öğrenci oluşturmaktadır. Veriler, Çocuklar İçin Bilgisayar Oyunu Bağımlılığı Ölçeği ile Bireysel ve Sosyal Sorumluluk Ölçeği ile toplanmıştır. Araştırma sonuçları, örneklem grubunun \% 53,4'ünün normal kullanıcı, \% 41,4'ünün problemli kullanıcı ve \% 6,2 'sinin bilgisayar oyunu bağımlısı olduğunu göstermektedir. Öğrencilerin bilgisayar oyun bağımlılığı puanları ile bireysel ve sosyal sorumluluk davranışı puanları arasında zayıf düzeyde $(r=, 046)$ negatif yönlü ve anlamlı bir ilişki ortaya konmuştur. Bilgisayar oyun bağımlılığının cinsiyet, kişisel bilgisayara ve akıllı telefona sahip olma açısından değişmekte olduğu; sınıf düzeyi (görevleri aksatma boyutu hariç) ve aile gelir düzeyi açısından anlamlı farklılık göstermediği saptanmıştır.

\section{Abstract}

Play is an activity in which the child discovers life, parti-cipates in a social environment with his peers, and constructs his talent and knowledge. In the past, the games played on the street or in the natural environment more are now being played online. This study was conducted to examine whether secondary school students' computer game addiction levels differ significantly according to gender, grade level, family income level, and having a personal computer, and the relationship between computer game addiction and responsibility behavior. The sample of the study consists of 352 volunteer students selected by simple random sampling method among $7^{\text {th }}$ and $8^{\text {th }}$ grade students studying in five state secondary schools in Aydın city center. The data were collected using the Children's Computer Game Addiction Scale and the Personal and Social Responsibility Scale. Research results showed that $53.4 \%$ of the sample group was found as normal user, $41.4 \%$ was problemematic user and $6.2 \%$ was computer game addicts. A weak $(r=, 046)$ negative and significant relationship was found between the students' computer game addiction scores and their personal and social responsibility behavior scores. It was found that computer game addiction scores changed in terms of gender, having a personal computer and smart phone; there was no significant difference in terms of class level (except for the disruption of duties) and family income level.

\footnotetext{
${ }^{1}$ Sorumlu Yazar, Aydın Adnan Menderes Üniversitesi, Eğitim Fakültesi, Eğitim Bilimleri, Aydın, TÜRKiYE; https://orcid.org/ 0000-0002-9264-3665 ${ }^{2}$ Milli Eğitim Bakanlığı, TÜRKiYE; https://orcid.org/0000-0003-3491-7143
} 


\section{Introduction}

Play is an activity in which the child discovers life, participates in a social environment with his peers and constructs his talent and knowledge. Games also differ according to the developmental periods of the child and the innovations brought by life. While street games were widespread in the past, virtual games played in home and cafes come to the forefront (Horzum, 2011). In the early days, video games played from consoles connected to televisions and machines in arcades were later played via tablet, desktop computer (PC), laptop, digital game console, smart phone. The time that children and adolescents spend on video games is increasing (Anderson, Gentile and Buckley, 2007; as cited in Gentile, 2009). It can be said that digital game addiction increases as the time spent on the game increases. Studies have found that the level of pathological play and digital game addiction among boys and adolescents between the ages of 8 and 18 are higher than girls (Gentile 2009, Horzum 2011). It is increasingly popular among young people (Yalçın Irmak and Erdoğan, 2016).

The aim of this study is to investigate the relationship between digital game addiction and responsibility behavior of $7^{\text {th }}$ and $8^{\text {th }}$ grade students in Aydın. Responsibility value is among the root values that should be gained to students in primary and secondary education programs. In this study, the effect of computer game addiction on responsibility value among children was examined. The following sub-problems are written below:

1. What are the computer game addiction levels of middle school students?

2. Do the computer game addiction levels of secondary school students differ significantly according to their personal variables (Gender,

Class level, Socioeconomic Level (HIA), having personal computer)?

3. Is there a significant relationship between secondary school students' level of computer game addiction and responsibility behav-ior?

4. Is the level of computer game addiction of secondary school students a significant predictor of the level of responsibility behavior?

\section{Method}

This research is designed in accordance with the correlational survey model, which is one of the quantitative research methods. In this context, the relationship between digital game addiction levels and responsibility behavior levels of secondary school students was examined.The sample of the study consists of 352 secondary school students in 5 secondary schools in the city of Aydın in the 2018 - 2019 academic year selected by simple random sampling method in Aydın city center in the study universe. In the simple random sampling method, all units that make up the universe have equal chances (Karasar, 2018).In this study, the data were collected using a Personal Information Form, the Children's Computer Game Addiction Scale (Horzum, Ayas, \& Balta, 2008) and the Personal and Social Responsibility Scale (Filiz \& Demirhan, 2015).

\section{Result and Discussion}

The results show that computer game addiction is an important risk factor for children. The addiction level of digital games results in children's inability to give up playing and being disturbed when they are blocked, making computer games live in their dreams and associating them with real life, disrupting their personal and family and school duties due to playing games and preferring games to other activities. Problems such as physical disturbances, psychological problems, loneliness, and social phobia caused by playing computer games for a long time can be experienced as a result of the child being uncontrolled and addicted to the game. Nowadays, digital games that are easily accessible on mobile, personal computers and all online devices can cause unwanted results if they are not played in a controlled manner.In this study, it was determined that more than half of the sample group were normal users and less than half of them were problematic users (41.4\%) or computer game addicts (6.2\%). Computer game addiction varies in terms of gender, owning a personal computer and smartphone, and does not differ significantly in terms of class level total score and family income level. Also a negative but significant correlation was found between total computer game addiction and total scores of individual and social responsibility. Computer game addiction predicted individual and social responsibility behaviors under $5 \%$. It can be inferred that this is effective if families put time limits on their children and allow them to play computer games during holidays. At this point, families should direct the child in accordance with the use of technology. It is an important necessity for our children to ensure that the future of schools and their families and children are encouraged to use technology correctly and consciously. In this study, digital game addiction was associated with the value of responsibility based on the statements obtained from one-toone interviews with teachers before carrying out the study, based on the value gains, which were renewed in 2017-2018 and constitute the main focus of the curriculum. Researchers may be advised to conduct qualitative and longitudinal research on digital game addiction and different variables in global age, where children are becoming increasingly acquainted with technology. 
Giriş

Oyun, çocuğun hayatı keşfettiği, akranlarıyla sosyal ortama katıldığı, yetenek ve bilgilerini yapılandırdığı bir faaliyettir. Gelişim dönemlerine ve ihtiyaçlarına uygun olarak çocukların oynadıkları oyun tercihleri değişim göstermektedir. Bilişim çağı olarak nitelendirilen bu dönemde çağın getirdiği yenilikler oyunları da farklılaştırmıştır; sokaklarda ve bahçelerde oynanan geleneksel oyunlar yerini bilgisayar araçlara bırakmıştır. ilk zamanlarda televizyonlara bağlanan konsollardan, atari salonlarındaki makinelerden oynanan video oyunları daha sonraları tablet, masaüstü bilgisayar (PC), dizüstü bilgisayar, bilgisayar oyun konsolu, akıllı telefon vasıtasıyla oynanmaktadır. Dolayısıyla işleme gücü ve erişim kolaylığı ile bilgisayar teknolojilerin kullanımındaki bu devrim, bilgisayar teknolojilere ve video oyunlarına harcanan zaman gibi çocukların ve ergenlerin bu tür teknolojileri kullanımının çarpıcı bir şekilde artmasına sahne olmuştur (Anderson, Gentile ve Buckley, 2007; Akt. Gentile, 2009).

Bilgisayar araçlara ulaşım kolaylığı arttıkça çocukların geçmiş yıllara kıyasla bilgisayar oyunlarla tanışıklığının daha erken başladığı, eğitim durumlarına göre ilkokulda öğrenim gören öğrencilerin bilgisayar oyunlarla tanışma yaşının lise öğrencilerine göre istatistiksel olarak daha erken yaşta başladığı saptanmıştır (Mustafaoğlu ve Yasacı, 2018). Teknolojiyle doğan ve z ve alfa kuşağı olarak nitelendirilen gençlerin teknolojiyi hayatına daha fazla kattığı ve bilgisayar oyunların gençler arasında giderek daha fazla popüler olduğu hatta bilgisayar oyunların gençler arasında popüler kültür imgesi olduğu bir dönemin yaşandığı görülmektedir (Yalçın Irmak ve Erdoğan, 2016). Bu durum popülerliğin de ötesine giderek hastalık olarak nitelendirilmiştir. Şöyle ki Amerikan Psikiyatri Birliği (APA) 2013 yılında yayınladı̆̆ı Ruhsal Bozuklukların Tanısal ve İstatistiksel El Kitabı-5 (DSM 5) 3. bölümünde internet oyunları potansiyel bir bozukluk olarak tanımlanmış ve internetin sık sık kullanılması, çoğu zaman oyunlarla meşgul olunması sebebiyle yaşanan sıkıntılar ve ruhsal bozukluklar belirtilen ölçütler çerçevesinde bağımlılık kategorisinde yer almıştır. Dünya sağlık örgütü (WHO) tarafından 2018 yılında yayınlanan Uluslararası hastalık sınıflandırılma (ICD-11) sistemine göre bilgisayar oyun bağımlılığı hastalık kategorisinde yer almıştır. ICD-11 raporunda oyun bağımlılığ "kontrol dışı oyun oynama, günlük hayatta yapılacak işlere ve diğer ilgi alanlarına oranla önceliği oyuna verme, negatif sonuçlarına rağmen oyun oynamayı devam ettirme" şeklinde tanımlanmıştır. Ayrıca bu semptomların oyun bağımlılığı olarak nitelendirilebilmesi için en az 12 ay süreyle kişisel, ailevi, sosyal, eğitimsel ve diğer önemli alanlarda kişide ciddi problemler yaratması gerektiği ifade edilmiştir (https://www.who.int). Türkiye Yeşilay Cemiyeti [YEŞiLAY] (2017) benzer olarak bağımlılık kavramını "kişinin kullandığı bir nesne veya bir eylem üzerindeki kontrolünü kaybetmesi ve onsuz yaşam sürememeye başlaması" şeklinde tanımlamıştır.

Bağımlılık olarak nitelendirilmese de gençlerin bilgisayar oyunlara harcadıkları süre arttıkça, başta kendi psikolojik durum bozuklukları olmak üzere, aile, yakın çevre, okul performansı ve sosyal ilişkilerini olumsuz yönde etkilediği söylenebilir. Amerika'da ulusal bir örneği temsilen 8 ila 18 yaş arasındaki gençlerin, \%8.5 oranındaki video oyun kullanıcılarının aile, sosyal, okul veya psikolojik işleyişe zarar veren onbir semptomdan en az altısını sergileyerek tanımlanan patolojik oyun kalıpları sergilediğini gözlemlenmiştir (Griffiths, 2009). Benzer şekilde yapılan araştırmaların sonuçlarına göre teknolojinin ölçüsüz kullanımının takım halinde çalışma, paylaşma becerilerini azalttığı, bireylerin kendine, ailesine ve topluma karşı sorumluluk duygularını zayıflatlattı̆̆ı ve bununla birlikte çocuklarda duygusal gelişimi engellediğini ifade etmiştir (Plowman, McPake \& Stephen, 2010; Akt. Mustafaoğlu, Zirek, Yasacı, Razak ve Özdinçler, 2018). Griffts \& Davies (2005) bağımlılığın temel bileşenleri açısından değerlendirildiğinde oyun bağımlılığının gençlerde alkol kullanımı ve uyuşturucu bağımlılığından farksız olduğunu ifade etmiş ve söz konusu bağımlılık bileşenlerini öncelikli olarak belirginlik (dikkatini çeken), hoşgörü, uzaklaşma, ruh hali değişimleri, çatışma ve tekrar nüksetme şeklinde belirtmiştir. Bu çalışmada araştırılan konu bağımlılı̆ın ilk bileşeni olarak nitelendirilen, kişinin zihinsel faaliyetlerini oyun üzerine odaklanmasıyla belirginleşen oyun fikrinin bireysel ve sosyal anlamda yerine getirmesi gereken görev ve sorumlulukları aksatmaya başlaması ile ilişkilendirilmesi üzerine temellendirilmiştir.

Bireysel ve sosyal sorumluluk kavramları 1970'li yıllarda özellikle lise öğrencilerinin agresif davranışlarının önüne geçebilmek adına karakter eğitimine yönelik uygulamalara katkı sağlamak amacıyla literatürde yerine almıştır (Buğdaycı, 2019). 2000'li yıllarda ise çekirdek aile yapısının da etkisiyle aile bağııı̆ının azalması, gençlerin etik değerlerini aşındıran olumsuz yayınlar ve evrensel ahlaki değerlerin gençlere kazandırılması ihtiyacı gibi sebeplerden dolayı sadece Türkiye'de değil tüm dünyada okullarda karakter eğitimi uygulamalarını yeniden gündeme getirmiştir (Lickona, 1996; Akt. Ekşi ve Katılmış, 2016). Türkiye'de Milli Eğitim Bakanlığı (MEB) değer kavramını "Değerlerimiz toplumumuzun millî ve manevi kaynaklarından damıtılarak dünden bugüne ulaşmış ve yarınlarımıza aktaracağımız öz mirasımızdır" olarak tanımlayarak tüm öğretim programlarının içine "dürüstlük, adalet, dostluk, özdenetim, saygı, sevgi, sabır, sorumluluk, vatanseverlik ve yardımseverlik" adı altında 10 kök değer yerleştirmiştir (MEB, 2018). Birleşmiş Milletler Eğitim, Bilim ve Kültür Örgütü (UNESCO) değerler eğitimini; “Çocukların ve gençlerin pozitif değerleri keşfedip geliştirmeleri ve kendi potansiyellerine göre ilerlemeleri için yürütülen eğitimsel gayretler" olarak tanımlayıp ve "yardımlaşma, özgürlük, mutluluk, dürüstlük, alçak gönülülük, sevgi, barış-huzur, saygı, sorumluluk, sadelik, tolerans ve birlik" değerlerini temel değerler olarak ifade etmiştir. Bu sebeple bu çalışmada MEB ve UNESCO'da ortak bileşen olarak ele alınabilen sorumluluk değeri ile araştırmacılar tarafından farklı terminolojiler ile video oyunu olarak ifade edilen ve bilgisayar oyun bağımlılığı kapsamında yer alan bilgisayar oyun bağımlıı̆̆ı arasındaki ilişki ele alınmıştır.

Sorumluluk kelimesinin genel Türkçe sözlük karşılığı "kişinin kendi davranışlarını veya kendi yetki alanına giren herhangi bir olayın sonuçlarını üstlenmesi, sorum, mesuliyet" (www.tdk.gov.tr) olarak tanımlanmıştır. Felsefe ve psikoloji alanları sorumluluğu farklı açılardan ele almakta ve incelemektedir. Felsefe sorumluluğun ahlaki boyutuyla, danışma psikolojisi ise daha çok danışanının daha etkili bir yaşam sürmesi ve kendisinin ve yaşamındaki diğer insanların yaşamlarını kolaylaştırma yolu, bir bakıma kişilik özelliği şeklinde ifade etmektedir (Yener, 2015). Eğitim ortamlarında sorumluluk aileler ve öğretmenler tarafından daha çok bireysel anlamda öğrencinin verilen bir görevi zamanında yerine getirip getiremediği ile ilgilenmektedir. Bununla birlikte sorumluluk 
kavramı 2017-2018 yılında yenilenen tüm ilköğretim programlarında öğrencilere kazandııılması gereken kök değerler arasında yer almaktadır.

Dewey' in de ifade ettiği gibi temelde bireysel ve sosyal anlamda sorumluluk alabilen ve sorumluluğunun farkında olan bireylerin zihninin sağlam ve dengeli bir şekilde gelişebileceği düşünülmektedir. Bu anlayışla sorumluluk kavramının zıttı sorumsuzluk, eğitim öğretim ortamlarında ister davranışı ister duyguyu ya da bir değeri nitelesin, son günlerde öğretmenlerin ve ailelerin çocuklarla ilgili yaygın olarak şikayet ettikleri bir sorun haline gelmiştir. Buradan hareketle değerler eğitiminin, gençlerin ve çocukların teknolojiyi yanlış ve aşırı kullanma ve bilgisayar oyun bağımlılığını önlemde etkili olabileceği düşünülmektedir. Alanyazın incelendiğinde sorumluluk davranışının beden eğitimi spor yoluyla kazandırılabileceği görüşüyle farklı yaş gruplarında sorumluluk düzeyleri ve fiziksel egzersiz, oyun, spor arasındaki ilişkileri inceleyen bazı çalışmalara rastlanmıştır (Buğdaycı, 2019; Bayraktar, Tozoğlu, Gülbahçe, Öztürk, Gülbahçe, 2016; Tazegül, 2014); ancak spor salonlarının yerini atari ve bilgisayar salonları; spor ve fiziksel aktivitelerin yerini bilgisayar ekranlarının ve akıllı telefonların başında oturan öğrencilerin yaygınlaşması göz önüne alındığında bilgisayar oyun bağımlılı̆ı ile sorumluluk davranışı ilişki üzerine bir çalışmaya rastlanamamıştır. Alanyazındaki ilgili araştırmalardan farklı olarak bu çalışmada ortaokul öğrencilerinin bilgisayar oyun bağımlılı̆̆ ile sorumluluk davranışı arasındaki ilişki saptanmaya çalışılmıştır.

\section{Araştırmanın Amacı}

Bu çalışmanın temel amacı, Aydın il merkezindeki 7. ve 8. sınıf öğrencilerinin bilgisayar oyun bağımlılığı düzeylerinin cinsiyet, sınıf düzeyi, ailenin gelir düzeyi, kişisel bilgisayara sahip olma değişkenlerine göre anlamlı farklılık gösterip göstermediğini ve bilgisayar oyun bağımlılığı ile sorumluluk davranışı arasındaki ilişkiyi incelemektir.

Bu temel amaç doğrultusunda aşağıda belirtilen alt problemlere yanıt aranmıştır:

1. Ortaokul öğrencilerinin bilgisayar oyun bağımlılıkları ne düzeydedir?

2. Ortaokul öğrencilerinin bilgisayar oyun bağımlılık düzeyleri cinsiyet, sınıf düzeyi, ailenin gelir düzeyi, kişisel bilgisayara sahip olma değişkenlerine göre anlamlı farklılık göstermekte midir?

3. Ortaokul öğrencilerinin bilgisayar oyun bağımlılık düzeyi ile sorumluluk davranışı arasında anlamlı bir ilişki var mıdır?

4. Ortaokul öğrencilerinin bilgisayar oyun bağımlılık düzeyi, sorumluluk davranış düzeyinin manidar bir yordayıcısı mıdır?

\section{YÖNTEM}

\section{Araştırmanın Modeli}

Bu çalışma nicel araştırma yöntemlerinden “ilişkisel tarama modeli” ne uygun olarak desenlenmiştir. Karasar’a göre (2018: 114) "ilişkisel tarama modeli, iki ya da daha çok değişken arasında birlikte değişim varlığını veya derecesini belirlemeyi amaçlayan araştırma modelidir". Bu kapsamda, ortaokul öğrencilerinin bilgisayar oyun bağımlılık düzeyleri ile sorumluluk davranış düzeyleri arasındaki ilişki incelenmiştir.

\section{Çalışma Grubu}

Araştırmanın çalışma grubunu 2018 - 2019 Eğitim - Öğretim yılı Aydın il merkezindeki, basit seçkisiz örnekleme yöntemiyle seçilmiş 352 ortaokul öğrencisi oluşturmaktadır. Basit seçkisiz örnekleme yönteminde evreni oluşturan tüm birimlerin eşit seçilme şansı vardır (Karasar, 2018). Çalışma grubu demografik özellikleri Tablo 1. de verilmiştir.

Tablo 1. Çalışma grubu özellikleri

\begin{tabular}{lccc}
\hline Değişkenler & & $\mathrm{N}$ & $\%$ \\
\hline \multirow{2}{*}{ Cinsiyet } & Kız & 198 & 56,3 \\
& Erkek & 154 & 43,8 \\
\hline \multirow{2}{*}{ Sınıf düzeyi } & 7 & 207 & 58,8 \\
& 8 & 145 & 41,2 \\
\hline \multirow{3}{*}{ Bilgisayar oyun türü } & Hiç Oynamadım & 43 & 12,2 \\
& Aksiyon/macera & 161 & 45,7 \\
& Spor/yarış & 30 & 8,5 \\
& Strateji & 40 & 11,4 \\
& Bulmaca/zeka & 35 & 9,9 \\
\hline Toplam & Dövüş/şiddet & 43 & 12,2 \\
\hline
\end{tabular}

Aydın İl Milli Eğitim Müdürlüğü tarafından alınan ölçek uygulama izni doğrultusunda zaman, maliyet ve ulaşım kolaylığı göz önüne alınarak belirlenen ve il merkezinde yer alan beş okulda öğrenim gören gönüllü 7. ve 8. sınıf öğrencileri çalışma grubunu oluşturmuştur. Dersleri aksatmayacak şekilde okul yöneticilerinden izin alınarak ve her bir okuldan iki şube seçilerek örneklem oluşturulmuştur. Hatalı ve eksik doldurulan veriler değerlendirmeye alınmayıp toplam 352 öğrenci çalışmaya dahil edilmiştir. 


\section{Veri Toplama Araçları}

Bu çalışmada veriler, Çocuklar İçin Bilgisayar Oyunu Bağımlılığı Ölçeği (Horzum, Ayas ve Balta, 2008) ve Bireysel ve Sosyal Sorumluluk Ölçeği (Filiz ve Demirhan, 2015) ile toplanmıştır. Horzum, Ayas ve Balta (2008) tarafından geliştirilen Çocuklar İçin Bilgisayar Oyunu Bağımlıı̆ı̆ Ölçeği 5’li Likert tipindedir. Ölçekte katılımcıların verebilecekleri yanıtlar “Her zaman (5), Sık sık (4), Bazen (3), Nadiren (2) ve Hiçbir zaman (1)" şeklinde oluşturulmuştur. Ölçek toplam 21 madde ve dört faktörlü yapıdan oluşmaktadır ve ölçekte ters madde bulunmamaktadır. İç tutarlıık testi sonuçlarında ölçek alt boyutlarının .50 (bilgisayar oyunu oynamaktan dolayı görevleri aksatma ve bilgisayar oyunu oynamayı başka etkinliklere tercih etme), .60 (bilgisayar oyununu gerçek hayatıyla ilişkilendirme), .83 (bilgisayar oyunu oynamayı bırakamama) arasında değiştiği görülmektedir. Bu çalışmada ölçeğin toplam iç tutarlılık katsayısı .85 olarak bulunmuştur. Bu değerlere bakıldığında ölçeğin güvenilir ve geçerli olduğu söylenebilir. Ölçekten alınabilecek puanlar 21-105 arasında olup, puanlar yükseldikçe bağımlıık riski artmaktadır. Ölçekten alınan toplam puanlar ortaokul öğrencileri için yorumlanırken, 21-39 puan normal kullanıcı, 40-72 puan problemli kullanıcı ve 73-105 puan ise bilgisayar oyunu bağımlısı olarak değerlendirilmektedir (Karaca ve diğerleri, 2016).

Araştırmada kullanılan ikinci ölçme aracı Li, Wright, Rukavina ve Pickering tarafından (2008) ortaokul yaş grubu öğrencileri üzerinde geliştirilen Bireysel ve Sosyal Sorumluluk Ölçeğidir. Filiz ve Demirhan (2015) tarafından Türkçe'ye uyarlanan ölçeğin orjinal hali ve dil uyarlama çalışması yaşları 9-15 arasında değişen ortaokul öğrencileri üzerinde yapılmışıı. Orjinali Beden Eğitimi ve Spor alanında okuyan öğrenci örneklemi üzerinde geliştirilen ölçek maddeleri incelendiğinde bireysel ve sosyal sorumluluk değerlerini kapsayan genel ifadeler yer aldığı görülmektedir; özel bir alan olarak beden eğitimi ve sporu içeren ifadeler olmadığı için eğitim bilimleri alanlardaki çalışmalarda da kullanılabileceği ifade edilmiştir ve çalışmanın amacına hizmet etmektedir. Ölçekte yer alan sorumlulukla ilgili her ifade "Kesinlikle Katılmıyorum (1)" ile "Kesinlikle Katılıyorum (6)" olmak üzere 6'lı Likert maddesi şeklinde puanlanmaktadır. Orijinali İngilizce olan ve sosyal ve bireysel sorumluluk adları altında iki boyuttan oluşan ölçeğin Türkçe versiyonu toplam 13 maddeden ve tek boyuttan oluşmaktadır. Ölçekte ters madde bulunmamaktadır. Ölçekten alınabilecek en düşük puan 13, en yüksek puan $78^{\prime}$ dir. Bu çalışmada ölçeğin Cronbach alpha güvenirlik katsayısı .94 olarak hesaplanmışır. Buna göre ölçek örneklem grubu için güvenilir bir ölçme aracıdır. Ölçekten alınan toplam puanlar yükseldikçe sorumluluk davranış düzeyi yükselmektedir. Bu çalışmada ölçeğin Cronbach alpha güvenirlik katsayısı .94 olarak hesaplanmıştır. Buna göre ölçek örneklem grubu için güvenilir bir ölçme aracıdır. Ölçekten alınan toplam puanlar yükseldikçe sorumluluk davranış düzeyi yükselmektedir.

\section{Verilerin Analizi}

Uygulanan 400 ölçekten hatalı ve eksik doldurulan veriler çıkarıldıktan sonra 352 anketin analizi yapılmıştır. Verilerin analizi için SPSS paket programı kullanılmıştır. Ölçeklerden alınan toplam puanların normallik varsayımını karşılamasını sınamak için çarpıklık ve basıkık değerlerine bakılmıştır. Bilgisayar oyun bağımlılı̆ı ölçeği toplam puanlarının çarpıklık değeri .77; basıklık değerinin ise .08 olduğu görülmüştür. Bireysel ve sosyal sorumluluk ölçeğinden alınan toplam puanların çarpıklık değeri 2.12 ve basıklık değeri ise 5.6 olarak hesaplanmıştır. Bireysel ve sosyal sorumluluk ölçeğinden alınan toplam puanların çarpıklık ve basıklık değerlerinin \pm 1 aralığında olmadı̆̆ı için normallik varsayımını sağlamadı̆̆ı değerlendirilmiştir (Can, 2018: 85). Kolmogorov-Smirnov testi sonuçlarına göre hem bilgisayar oyun bağımlılığı toplam puanlarında hem de bireysel ve sosyal sorumluluk ölçeğinden alınan toplam puanlarında dağılımların normal dağııma uygun olmadığı belirlenmiştir. Yapılan analizlere göre verilerin analizinde nonparametrik testler kullanılmıştır. Bağımsız değişkenler arasındaki ilişkinin incelenmesi için Kruskal-Wallis Testi ve Mann-Whitney U Testi kullanıımışır. Manidarık düzeyi $p<0,05$ olarak alınmıştır. Sorumluluk davranış toplam puanları ve bilgisayar oyun oynama düzeyi ölçeğinden alınan toplam puanlar arasındaki ilişkinin düzeyini ve yönünü hesaplamak için Spearman Sıra Farkları Korelasyon analizi yapılmışır. Bilgisayar oyun bağımlılı̆ının sorumluluk davranışlarını yordama gücünü belirlemek için Basit Doğrusal Regresyon analizi uygulanmıştır.

\section{BULGULAR}

Bu bölümde araştırmaya katılan ortaokul öğrencilerinin bilgisayar oyun bağımlılık düzeyleri incelenmiştir. Birinci alt probleme yönelik katılımcıların bilgisayar oyun bağımlılık düzeylerini belirlemek amacıyla bilgisayar oyun bağımlılığı ölçeği ile toplanan verilerin minimum, maksimum, ortalama puan ve standart sapma sonuçları bulunmuştur. Belirtilen istatistiki veriler Tablo 2 'de sunulmuştur.

Tablo 2. Bilgisayar oyun bağımlılığı düzeylerine ilişkin betimsel istatistikler

\begin{tabular}{|c|c|c|c|c|c|}
\hline Alt boyutlar & $\mathrm{N}$ & Min & Max & $X^{-}$ & Ss \\
\hline $\begin{array}{l}\text { Bilgisayarda oyun oynamaktan vazgeçememe ve } \\
\text { engellendiğinde rahatsız olma }\end{array}$ & 352 & 10,00 & 49,00 & 22,38 & 9,93 \\
\hline $\begin{array}{l}\text { Bilgisayar oyununu hayalinde yaşatma ve gerçek hayatıyla } \\
\text { ilişkilendirme }\end{array}$ & 352 & 4,00 & 20,00 & 7,09 & 3,42 \\
\hline Bilgisayar oyunu oynamaktan dolayı görevleri aksatma & 352 & 3,00 & 15,00 & 4,30 & 2,01 \\
\hline Bilgisayar oyunu oynamayı başka etkinliklere tercih etme & 352 & 4,00 & 20,00 & 7,31 & 3,45 \\
\hline Toplam Puan & 352 & 21,00 & 89,00 & 41,09 & 16,44 \\
\hline
\end{tabular}


Araştırmada öğrencilerin bilgisayar oyunu bağımlılığı ölçeğinden alınan puan ortalaması 41,09 $\pm 16,44$ 'tür. Ölçekten alınan toplam puanlar ortaokul öğrencileri için yorumlanırken, 21-39 puan normal kullanıcı, 40-72 puan problemli kullanıcı ve 73-105 puan ise bilgisayar oyunu bağımlısı olarak değerlendirildiğinde katılımcıların $\boldsymbol{X}^{-}=41.09$ ortalama ile bilgisayar oyun bağımlılık düzeylerinin problemli kullanım düzeyinde olduğu söylenebilir. Bu sonuçlara göre bilgisayar oyun bağımlılığı ölçeği puan ortalamaları bakımından örneklem grubunun \% 53,4'ünün normal kullanıcı, \% 41,4'ünün problemli kullanıcı ve \% 6,2'sinin bilgisayar oyunu bağımlısı olduğu belirlenmiştir. Ölçeğin alt boyutlarına ilişkin sonuçlar incelendiğinde en yüksek puanın "bilgisayarda oyun oynamaktan vazgeçememe ve engellendiğinde rahatsız olma” boyutunda gerçekleştiği görülmektedir.

\section{íkinci Alt Probleme illişkin Bulgular}

Araştırmanın ikinci alt probleminde araştırmaya katılan ortaokul öğrencilerinin bilgisayar oyun bağımlılığı düzeylerinin; cinsiyet, sınıf düzeyi, aile gelir düzeyi, kişisel bilgisayar ve akıllı telefon sahibi olma değişkenlerine göre manidar bir fark gösterip göstermediği incelenmiştir. Ortaokul öğrencilerinin bilgisayar oyunu bağımlılığı düzeylerinin cinsiyet değişkenine göre manidar bir fark gösterip göstermediğine ilişkin bulgular Tablo 3'te verilmektedir.

Tablo 3. Bilgisayar oyun bağımlılığı düzeylerinin cinsiyete göre Mann Whitney U-testi sonuçları

\begin{tabular}{|c|c|c|c|c|c|c|}
\hline Alt Boyutlar & Cinsiyet & $\mathrm{N}$ & Sıra Ortalaması & Sıra Toplamı & $U$ & $p$ \\
\hline \multirow{2}{*}{$\begin{array}{l}\text { Bilgisayarda oyun oynamaktan } \\
\text { vazgeçememe ve engellendiğinde } \\
\text { rahatsız olma }\end{array}$} & $\mathrm{K} ı \mathrm{z}$ & 198 & 144,46 & 28604,00 & \multirow[b]{2}{*}{8903,00} & \multirow[b]{2}{*}{.00} \\
\hline & Erkek & 154 & 217,69 & 33524,00 & & \\
\hline \multirow{2}{*}{$\begin{array}{l}\text { Bilgisayar oyununu hayalinde yaşatma } \\
\text { ve gerçek hayatıyla ilişkilendirme }\end{array}$} & $\mathrm{K} ı \mathrm{z}$ & 198 & 138,15 & 27353,00 & \multirow{2}{*}{7652,00} & \multirow{2}{*}{.00} \\
\hline & Erkek & 154 & 225,81 & 34775,00 & & \\
\hline \multirow{2}{*}{$\begin{array}{l}\text { Bilgisayar oyunu oynamaktan dolayı } \\
\text { görevleri aksatma }\end{array}$} & $\mathrm{K} 1 \mathrm{Z}$ & 198 & 147,01 & 29108,50 & \multirow{2}{*}{9407,50} & \multirow{2}{*}{.00} \\
\hline & Erkek & 154 & 214,41 & 33019,50 & & \\
\hline \multirow{2}{*}{$\begin{array}{l}\text { Bilgisayar oyunu oynamayı başka } \\
\text { etkinliklere tercih etme }\end{array}$} & $\mathrm{K} \mathrm{Iz}$ & 198 & 145,62 & 28832,00 & \multirow{2}{*}{9131,00} & \multirow{2}{*}{.00} \\
\hline & Erkek & 154 & 216,21 & 33296,00 & & \\
\hline \multirow{2}{*}{ Toplam Puan } & $\mathrm{K} \mathrm{IZ}$ & 198 & 138,87 & $27.496,00$ & \multirow{2}{*}{7795,00} & \multirow{2}{*}{.00} \\
\hline & Erkek & 154 & 224,88 & 34632,00 & & \\
\hline
\end{tabular}

Tablo 3 incelendiğinde, katılımcıların bilgisayar oyunu oynama düzeyini, cinsiyete göre karşılaştırmak amacı ile yapılan Mann Whitney $U$ testi analizi sonuçlarına göre tüm faktörlerde ve tüm maddelerin yer aldığı toplam bağımlılık değerinde $(p<.05)$ manidar bir farklılık olduğu görülmüştür. Buradan hareketle erkek öğrencilerin bilgisayar oyunu oynama düzeyinin kız öğrencilere oranla daha yüksek olduğu söylenebilir.

Ortaokul öğrencilerinin bilgisayar oyunu bağımlılığı düzeylerinin sınıf düzeyi değişkenine göre manidar bir fark gösterip göstermediğine ilişkin bulgular Tablo 4'te verilmektedir:

Tablo 4. Bilgisayar oyun bağımlılığı düzeylerinin sınıf düzeyine göre Mann Whitney U-testi sonuçları

\begin{tabular}{|c|c|c|c|c|c|c|}
\hline Alt Boyutlar & Sınıf Düzeyi & $\mathrm{N}$ & Sıra Ortalaması & Sıra Toplamı & U & $\mathrm{P}$ \\
\hline \multirow{3}{*}{$\begin{array}{l}\text { Bilgisayarda oyun oynamaktan } \\
\text { vazgeçememe ve engellendiğinde } \\
\text { rahatsız olma }\end{array}$} & 7 & 207 & 176,07 & 36445,50 & \multirow{3}{*}{14917,50} & \multirow{3}{*}{.924} \\
\hline & & & & & & \\
\hline & 8 & 145 & 177,12 & 25682,50 & & \\
\hline \multirow{3}{*}{$\begin{array}{l}\text { Bilgisayar oyununu hayalinde } \\
\text { yaşatma ve gerçek hayatıyla } \\
\text { ilişkilendirme }\end{array}$} & 7 & 207 & 176,54 & 36543,50 & \multirow{3}{*}{14999,50} & \multirow{3}{*}{.993} \\
\hline & & & & & & \\
\hline & 8 & 145 & 176,44 & 25584,50 & & \\
\hline \multirow{2}{*}{$\begin{array}{l}\text { Bilgisayar oyunu oynamaktan dolayı } \\
\text { görevleri aksatma }\end{array}$} & 7 & 207 & 167,96 & 34768,00 & \multirow{2}{*}{13240,00} & \multirow{2}{*}{.041} \\
\hline & 8 & 145 & 188,69 & 27360,00 & & \\
\hline \multirow{2}{*}{$\begin{array}{l}\text { Bilgisayar oyunu oynamayı başka } \\
\text { etkinliklere tercih etme }\end{array}$} & 7 & 207 & 183,46 & 37975,50 & \multirow{2}{*}{13567,50} & \multirow{2}{*}{.119} \\
\hline & 8 & 145 & 166,57 & 24152,50 & & \\
\hline \multirow{2}{*}{ Toplam Puan } & 7 & 207 & 176,56 & $36.548,50$ & \multirow{2}{*}{14994,50} & \multirow{2}{*}{.989} \\
\hline & 8 & 145 & 176,41 & $25.579,50$ & & \\
\hline
\end{tabular}

$\mathrm{p}<.05^{*}$

Katılımcıların bilgisayar oyunu oynama düzeyini, sınıf düzeyine göre karşılaştırmak amacı ile yapılan Mann Whitney U testi analizi sonuçlarına göre öğrencilerin öğrenim gördükleri sınıflara göre bilgisayar oyunu oynamaktan dolayı görevleri aksatma alt faktöründe 8. sınıflar lehine anlamlı bir farklılık ( $p=.041)$ bulunmuştur. Toplam puan açısından değerlendirildiğinde ise $(p=0.989$; p >.05) hesaplanmış olup sınıf düzeyinin manidar bir farklılık yaratmadığı görülmüştür.

Ortaokul öğrencilerinin bilgisayar oyun bağımlılı̆̆ düzeylerinin aile gelir düzeyi değişkenine göre manidar bir fark gösterip 
göstermediğine ilişkin bulgular Tablo 5'te verilmektedir:

Tablo 5. Bilgisayar oyun bağımlılığının aile gelir düzeyine göre Kruskal-Wallis testi sonuçları

\begin{tabular}{|c|c|c|c|c|c|c|}
\hline Alt Boyutlar & $\begin{array}{c}\text { Aile gelir } \\
\text { durumu(TL) }\end{array}$ & $\mathrm{N}$ & $\begin{array}{c}\text { Sıra } \\
\text { Ortalama } \\
\text { sı }\end{array}$ & $\mathrm{Sd}$ & $x^{2}$ & $p$ \\
\hline \multirow{4}{*}{$\begin{array}{l}\text { Bilgisayarda oyun oynamaktan vazgeçememe ve } \\
\text { engellendiğinde rahatsız olma }\end{array}$} & $0-2000$ & 92 & 157,60 & 3 & \multirow{4}{*}{5,385} & \multirow{4}{*}{, 146 } \\
\hline & $2001-4000$ & 144 & 179,86 & 3 & & \\
\hline & $4001-6000$ & 69 & 193,97 & 3 & & \\
\hline & 6001 Ve üzeri & 47 & 177,56 & 3 & & \\
\hline \multirow{4}{*}{$\begin{array}{l}\text { Bilgisayar oyununu hayalinde yaşatma ve gerçek } \\
\text { hayatıyla ilişkilendirme }\end{array}$} & $0-2000$ & 92 & 165,49 & 3 & \multirow{4}{*}{1,680} & \multirow{4}{*}{,641 } \\
\hline & $2001-4000$ & 144 & 182,39 & 3 & & \\
\hline & $4001-6000$ & 69 & 179,41 & 3 & & \\
\hline & 6001 Ve üzeri & 47 & 175,74 & 3 & & \\
\hline \multirow{4}{*}{$\begin{array}{l}\text { Bilgisayar oyunu oynamaktan dolayı görevleri } \\
\text { aksatma }\end{array}$} & $0-2000$ & 92 & 174,77 & 3 & \multirow{4}{*}{1,159} & \multirow{4}{*}{ 763 } \\
\hline & $2001-4000$ & 144 & 182,24 & 3 & & \\
\hline & $4001-6000$ & 69 & 173,53 & 3 & & \\
\hline & 6001 Ve üzeri & 47 & 166,67 & 3 & & \\
\hline \multirow{4}{*}{$\begin{array}{l}\text { Bilgisayar oyunu oynamayı başka etkinliklere } \\
\text { tercih etme }\end{array}$} & $0-2000$ & 92 & 167,66 & 3 & \multirow{4}{*}{2,600} & \multirow{4}{*}{,457 } \\
\hline & $2001-4000$ & 144 & 175,53 & 3 & & \\
\hline & $4001-6000$ & 69 & 192,69 & 3 & & \\
\hline & 6001 Ve üzeri & 47 & 173,02 & 3 & & \\
\hline \multirow{4}{*}{ Toplam Puan } & $0-2000$ & 92 & 161,86 & 3 & \multirow{4}{*}{3,232} & \multirow{4}{*}{,357 } \\
\hline & $2001-4000$ & 144 & 179,94 & 3 & & \\
\hline & $4001-6000$ & 69 & 189,64 & 3 & & \\
\hline & 6001 Ve üzeri & 47 & 175,33 & 3 & & \\
\hline
\end{tabular}

Katılımcıların bilgisayar oyunu oynama düzeylerini, aile gelir düzeyine göre karşılaştırmak amacı ile yapılan Kruskal-Wallis analizi sonuçlarına göre $p$ değeri olduğundan $(p=0.357 ; p>.05)$ aile gelir düzeyine göre bilgisayar oyunu oynama düzeyleri arasında manidar bir farklılık olmadığı görülmüştür.

Ortaokul öğrencilerinin bilgisayar oyunu bağımlılı̆ı düzeylerinin bilgisayara sahip olma değişkenine göre manidar bir fark gösterip göstermediğine ilişkin bulgular Tablo 6'da verilmektedir:

Tablo 6. Bilgisayar oyun bağımlılığının kişisel bilgisayar sahibi olma değişkenine göre Mann Whitney U-testi sonuçları

\begin{tabular}{|c|c|c|c|c|c|c|}
\hline Alt Boyutlar & Cinsiyet & $\mathrm{N}$ & Sıra Ortalaması & Sıra Toplamı & $\mathrm{U}$ & $P$ \\
\hline \multirow{3}{*}{$\begin{array}{l}\text { Bilgisayarda oyun oynamaktan } \\
\text { vazgeçememe ve engellendiğinde } \\
\text { rahatsız olma }\end{array}$} & Evet & 189 & 196,59 & 37155,00 & \multirow{3}{*}{11813,500} & \multirow{3}{*}{,000 } \\
\hline & & & & & & \\
\hline & Hayır & 163 & 153,21 & 24973,00 & & \\
\hline \multirow{2}{*}{$\begin{array}{l}\text { Bilgisayar oyununu hayalinde yaşatma } \\
\text { ve gerçek hayatıyla ilişkilendirme }\end{array}$} & Evet & 189 & 195,49 & 36948,50 & \multirow{2}{*}{12052,500} & \multirow{2}{*}{, 000} \\
\hline & Hayır & 163 & 154,48 & 25179,50 & & \\
\hline \multirow{2}{*}{$\begin{array}{l}\text { Bilgisayar oyunu oynamaktan dolayı } \\
\text { görevleri aksatma }\end{array}$} & Evet & 189 & 194,23 & 36709,50 & \multirow{2}{*}{12846,000} & \multirow{2}{*}{, 004} \\
\hline & Hayır & 163 & 155,94 & 25418,50 & & \\
\hline \multirow{2}{*}{$\begin{array}{l}\text { Bilgisayar oyunu oynamayı başka } \\
\text { etkinliklere tercih etme }\end{array}$} & Evet & 189 & 190,03 & 35916,00 & \multirow{2}{*}{12350,500} & \multirow{2}{*}{,001 } \\
\hline & Hayır & 163 & 160,81 & 26212,00 & & \\
\hline \multirow{2}{*}{ Toplam Puan } & Evet & 189 & 196,59 & 37155,00 & \multirow{2}{*}{11607,000} & \multirow{2}{*}{,000 } \\
\hline & Hayır & 163 & 153,21 & 24973,00 & & \\
\hline
\end{tabular}

Tablo 6'da verilen öğrencilerin kişisel bilgisayara sahip olma durumu ile öğrencilerin bilgisayar oyunu oynama düzeyleri arasındaki ilişki incelendiğinde, bilgisayar sahibi olan öğrencilerin bilgisayar oyunu oynama düzeyinin toplam puan $(\boldsymbol{X}=196,59)$; bilgisayar sahibi olmayan öğrencilerden $\left(X^{-}=153,21\right)$ yüksek olduğu görülmektedir. U-testi sonuçlarına göre öğrencilerin bilgisayar oyunu oynama düzeyi, bilgisayar sahip olma durumuna göre tüm alt boyutlarda manidar farklılıklar göstermektedir ( $p<.05)$.

Ortaokul öğrencilerinin bilgisayar oyunu bağımlılığının akıllı telefona sahip olma değişkenine göre manidar bir fark gösterip göstermediğine ilişkin bulgular Tablo 7'de verilmektedir:

Tablo 7. Bilgisayar oyun bağımlılığı akıllı telefona sahip olma değişkenine göre değişimi u-testi sonuçları 


\begin{tabular}{|c|c|c|c|c|c|c|}
\hline Alt Boyutlar & $\begin{array}{l}\text { Akıllı telefona } \\
\text { sahip olma }\end{array}$ & $\mathrm{N}$ & $\begin{array}{c}\text { Sıra } \\
\text { Ortalaması }\end{array}$ & Sıra Toplamı & $U$ & $\mathrm{P}$ \\
\hline \multirow{3}{*}{$\begin{array}{l}\text { Bilgisayarda oyun oynamaktan } \\
\text { vazgeçememe ve engellendiğinde } \\
\text { rahatsız olma }\end{array}$} & Evet & 274 & 186,33 & 51054,50 & \multirow{3}{*}{7992,50} & \multirow{3}{*}{,001 } \\
\hline & & & & & & \\
\hline & Hayır & 78 & 141,97 & 11073,50 & & \\
\hline \multirow{3}{*}{$\begin{array}{l}\text { Bilgisayar oyununu hayalinde } \\
\text { yaşatma ve gerçek hayatıyla } \\
\text { ilişkilendirme }\end{array}$} & Evet & 274 & 184,11 & 50446,50 & \multirow{3}{*}{8600,50} & \multirow{3}{*}{,007 } \\
\hline & & & & & & \\
\hline & Hayır & 78 & 149,76 & 11681,50 & & \\
\hline \multirow{2}{*}{$\begin{array}{l}\text { Bilgisayar oyunu oynamaktan dolayı } \\
\text { görevleri aksatma }\end{array}$} & Evet & 274 & 187,30 & 51319,50 & \multirow{2}{*}{7727,500} & \multirow{2}{*}{,000 } \\
\hline & Hayır & 78 & 138,57 & 10808,50 & & \\
\hline \multirow{2}{*}{$\begin{array}{l}\text { Bilgisayar oyunu oynamayı başka } \\
\text { etkinliklere tercih etme }\end{array}$} & Evet & 274 & 185,80 & 50908,00 & \multirow{2}{*}{8139,000} & \multirow{2}{*}{,001 } \\
\hline & Hayır & 78 & 143,85 & 11220,00 & & \\
\hline \multirow{2}{*}{ Toplam Puan } & Evet & 274 & 187,63 & 51410,50 & \multirow{2}{*}{7636,50} & \multirow{2}{*}{,000 } \\
\hline & Hayır & 78 & 137,40 & 10717,50 & & \\
\hline
\end{tabular}

Tablo 7'de verilen öğrencilerin akıllı telefona sahip olma durumu ile öğrencilerin bilgisayar oyunu bağımlılığı arasındaki ilişki incelendiğinde, akıllı telefon sahibi olan öğrencilerin bilgisayar oyunu bağımlılığının $\left(\boldsymbol{X}^{\prime}=187,63\right)$; akıllı telefon sahibi olmayan öğrencilerden $\left(\boldsymbol{X}^{-}=137,40\right)$ yüksek olduğu görülmektedir. U testi sonuçlarına göre öğrencilerin bilgisayar oyunu bağımlılık düzeyi, akıllı telefona sahip olma durumuna göre tüm alt boyutlarda manidar bir farklılık göstermektedir $(p=, 000)$.

\section{Üçüncü Alt Probleme iliş̧kin Bulgular}

Araştırmanın üçüncü alt probleminde bilgisayar oyun bağımlılığı ölçeğinden alınan toplam puanlar ile bireysel ve sosyal sorumluluk ölçeğinden alınan toplam puanlar arasında manidar bir ilişki olup olmadığı incelenmiştir. Ortaokul öğrencilerinin bilgisayar oyun bağımlılığı ile bireysel ve sosyal sorumluluk davranışları arasında manidar bir ilişki olup olmadığına ilişkin bulgular Tablo 8'de verilmektedir:

Tablo 8. Ortaokul öğrencilerinin bilgisayar oyun bağımlılığı alt boyutları ile bireysel ve sosyal sorumluluk toplam puanları arasındaki ilişkiyi sınayan spearman sıra farkları korelasyon analizi sonuçları

\begin{tabular}{|c|c|c|c|}
\hline Alt Boyutlar & $\mathrm{N}$ & r & $P$ \\
\hline $\begin{array}{l}\text { Bilgisayarda oyun oynamaktan vazgeçememe ve engellendiğinde } \\
\text { rahatsız olma }\end{array}$ & 352 & $-.283(*)$ & .000 \\
\hline $\begin{array}{l}\text { Bilgisayar oyununu hayalinde yaşatma ve gerçek hayatıyla } \\
\text { ilişkilendirme }\end{array}$ & 352 & $-.255\left(^{*}\right)$ & .000 \\
\hline Bilgisayar oyunu oynamaktan dolayı görevleri aksatma & 352 & $-.313(*)$ & .000 \\
\hline Bilgisayar oyunu oynamayı başka etkinliklere tercih etme & 352 & $-248\left(^{*}\right)$ & .000 \\
\hline Bilgisayar Oyun Bağımlılığı Toplam & 352 & $-.312(*)$ & .000 \\
\hline
\end{tabular}

Korelasyon katsayısının 0 - .19 arasında olması ilişkinin bulunmadığına, .20 - .35 arasında olması zayıf ilişkinin olduğuna, .36 - .65 arasında olması orta düzeyde bir ilişkinin olduğuna, 0,66 - .85 arasında olması ise oldukça yüksek bir ilişkinin olduğuna ve .85 'ten büyük olması ise yüksek düzeyde ilişki olduğuna karşılık gelmektedir (Karasar; 2018: 300). Buna göre, Tablo 8 incelendiğinde, Bilgisayar oyunu bağımlılığı toplam puanları ve Bireysel ve Sosyal Sorumluluk toplam puanları arasındaki korelasyon katsayısı $r=0.31$ olarak hesaplanmıştır. Alt boyutlar açısından incelendiğinde ise bilgisayarda oyunu oynamaktan vazgeçememe ve engellendiğinde rahatsız olma, Bilgisayar oyununu hayalinde yaşatma ve gerçek hayatıyla ilişkilendirme, Bilgisayar oyunu oynamaktan dolayı görevleri aksatma, Bilgisayar oyunu oynamayı başka etkinliklere tercih etme alt boyutları ile Bireysel ve Sosyal Sorumluluk davranışları arasında negatif yönlü (-.248- -.312) arasında değişen anlamlı fakat zayıf bir ilişki olduğu görülmektedir. Başka bir ifadeyle bu çalışmada ele alınan iki değişken birbirlerini anlamlı, negatif yönde zayıf düzeyde etkilemektedir.

\section{Dördüncü Alt Probleme illişkin Bulgular}

Bilgisayar oyun bağımlılığının öğrencilerin sorumluluk davranışlarını yordayıp yordamadığına ilişkin yapılan regresyon analizine dair bulgular Tablo 9'da verilmektedir.

Tablo 9. Ortaokul öğrencilerinin bilgisayar oyun bağımlılı̆̆ı düzeylerinin bireysel ve sosyal sorumluluk davranışlarını yordama gücüne ilişkin regresyon analizi tablosu 


\begin{tabular}{lccccc}
\hline \multicolumn{1}{c}{ Model } & $\mathrm{B}$ & $\mathrm{T}$ & $\mathrm{R}$ & $\mathrm{R}^{2}$ & $\mathrm{~F}$ \\
\hline 1 &,- 159 & $-4,108$ &, $214 a$ &, 046 & 16,874 \\
a.Yordayıcl: & Bilgisayar Oyun Bağımlılı̆ı & & & & \\
\hline
\end{tabular}

${ }^{*} p<0.01$

Tablo 9 incelendiğinde; bilgisayar oyun bağımlılığının bireysel ve sosyal sorumluluk davranışlarını yordama gücü basit doğrusal regresyon analizi ile incelenmiş ve yapılan analiz sonucunda, bilgisayar oyun bağımlılı̆ının Bireysel ve Sosyal Sorumluluk davranışlarını düşük ve manidar düzeyde yordadığı bulunmuştur. Başka bir ifadeyle bilgisayar oyun bağımlılığı, Bireysel ve Sosyal Sorumluluk davranışlarının \% 4.6'sını $\left(R^{2} .046\right)$ yordamaktadır.

\section{TARTIŞMA}

Yurtdışı literatürde video oyun bağımlılığı ve DSM-5 verilerinde internet oyun bozukluğu olarak ifade edilen ve günümüzde popüler olarak bilgisayar oyun bağımlılığı çatısı altında yer alan bilgisayar oyunu bağımlılığı ile ilgili literatür incelendiğinde, araştırmalarda sıklıkla bağımlılık düzeyi, oyunların çocuklar üzerindeki olumlu ve olumsuz etkileri ve bilgisayar oyun oynama eğilimleri ortaya konulmuştur. Çocuk ve gençlerde bilgisayar oyun bağımlılı̆̆ ile ilgili araştırmalarda oyunların çocukların değerleri üzerindeki etkilerine ve sorumluluk davranışlarındaki değişime etkisini inceleyen çalışmalara yer verilmediği görülmüştür. Bu araştırmanın amacı ortaokul 7. ve 8. sınıf öğrencilerinin bilgisayar oyun bağımlılığı ile sorumluluk davranışı arasındaki ilişkiyi incelemek ve ortaokul öğrencilerinin bilgisayar oyun bağımlılık düzeylerinin cinsiyet, sınıf düzeyi, aile gelir düzeyi, kişisel bilgisayara sahip olup olma ve akılı cep telefonuna sahip olup olmama durumuna göre farklılık gösterip göstermediğini saptamak olarak ifade edilmiştir.

Araştırmada örneklem grubunun \% 53,4'ünün normal kullanıcı, \% 41,4'ünün problemli kullanıcı ve \% 6,2 'sinin bilgisayar oyunu bağımlısı olduğu saptanmıştır. Şahin ve Tuğrul'un (2012) ilköğretim 4. ve 5. sınıf öğrencileriyle yaptıkları çalışmada bilgisayar oyunu bağımlılığının düşük olduğu belirlenmiştir. Bu çalışmaların aksine aynı yıllarda yapılan farklı çalışmalarda Güllü, Arslan, Dündar ve Murathan (2012) 4.5.6.7. ve 8. Sınıf öğrencileri arasında yaptığı çalışma ile Keser ve Esgi'nin (2012) 12-15 yaş grubu öğrencilerle yaptığı çalışmada bilgisayar oyunu bağımlılığının bu çalışmaya göre yüksek olduğu saptanmıştır. Bilgin (2015) ortaokul öğrencileri ile yaptığı çalışmada öğrencilerin oyun bağımlılığı düzeyinin riskli olduğunu ortaya koymuştur. Eldeki Karaca ve ark. (2016) 10-15 yaş grubu öğrencilerle yaptığı çalışmada bilgisayar oyunu bağımlıı̆ı̆ının puan ortalamaları açısından örneklem grubunun bu çalışmaya benzer bir şekilde \%47,7'sinin normal kullanıcı, \%46,7'sinin problemli kullanıcı ve \%5,6'sının bilgisayar oyunu bağımlısı olduğu saptanmıştır. çalışmada örneklem grubunu oluşturan öğrencilerin ortaokul düzeyi olduğu düşünüldüğünde her ne kadar yarısından fazlası normal kullanıcı olarak saptansa da aynı zamanda yarıya yakınının problemli kullanıcı olması ve \%6'sının bağımlı kategorisinde yer alması kayda değer bir bulgu niteliği taşımaktadır. Yurt dışındaki çalışmalar incelendiğinde de Müller ve ark. (2015) 14-17 yaş grubundaki öğrencilerle yaptıkları çalışmada ergenlerin \%1,6'sının çevrimiçi oyun bağımlısı olduğunu, \% 5,1'inin ise risk altında olduklarını saptamıştır. Türkiye'de eğitim kapsamında sadece Milli Eğitim Bakanlığı değil; pek çok farklı kamu ve sivil toplum kuruluşu bu konudaki hassasiyet göstererek projeler ortaya koymaktadırlar. Bunun en yakın örneği 2018 yılı itibariyle Sağlık Bakanlığı öncülüğünde Yeşilay, Gençlik ve Spor Bakanlı̆̆ı, vb. kurumların bilgisayar bağımlılık ile ilgili düzenlenlediği çalıştayla alan uzmanları, akademisyenleri, öğretmenleri ve yetkilileri bir araya getirip çözüm yolu arayışına girmiş olmasıdır (https://sggm.saglik.gov.tr). Çalıştay raporuna göre çocukların uygunsuz oyunlarla oynamasının yalnızlaşma ve yabancılaşmaya neden olduğu belirtilerek bu çalışmada temel alınan 9-11 yaş grubunda, günlük yaşam aktivitelerini ve sosyal etkileşimini aksatmamak kaydıyla akademik aktiviteler dışında en fazla 2 saat olacak şekilde ailenin gözetiminde teknolojik araçları kullanabileceği yönünde bir öneri getirilmiştir.

Cinsiyet açısından araştırmada erkek öğrencilerin oyun oynamayı bırakamama, oyunu gerçek hayatıyla ilişkilendirme, oyunu oynamaktan dolayı görevleri aksatma, oyun oynamayı başka etkinliklere tercih etme ve toplam oyun bağımlılı̆ı düzeylerinin kız öğrencilere göre oldukça yüksek olduğu bulunmuştur. Bu bulgu Souza, Greenberg ve Lachlan (2003), Hauge ve Gentile, (2003), Erboy ve Vural (2010), Onay, Tüfekçi ve Çağıltay (2005), Horzum (2011), Keser ve Esgi (2012), Gökçearslan ve Durakoğlu (2014) ve Kuzu, Akbulut ve Sivacı (2018) çalışmalarındaki bulgular ile örtüşmektedir. Bu araştırmada ortaya çıkan bulguya göre, erkek öğrencilerin kız öğrencilere oranla daha çok şiddet/dövüş, aksiyon/macera ve hız oyunlarını tercih ettikleri saptanmıştır. Buna göre şiddet, aksiyon ve hız tutkunluğu eğilimi normal hayatta daha baskın olan öğrencilerin bu davranışlarını çevrimiçi oyunlarda da ortaya koydukları söylenebilir.

Araştırmada, öğrencilerin öğrenim gördükleri sınıflara göre bilgisayar oyunu oynamaktan dolayı görevleri aksatma alt faktöründe 8. sınıflar lehine anlamlı bir farklılık $(p=.041)$ bulunmuştur. Bununla birlikte diğer alt faktörlerde ve tüm maddelerin yer aldığı toplam bağımlılıkta anlamlı bir farklılık bulunmamıştır. Bu bulgu Şahin ve Tuğrul (2012) ile Taş, Eker ve Anlı (2014) çalışmalarındaki bulgularla örtüşmektedir. Ancak Güllü ve diğerlerinin (2012) ilköğretim öğrencileri arasında yaptığı çalışmada sınıf düzeyine göre bilgisayarda oyun oynamaktan vazgeçememe ve engellendiğinde rahatsız olma ve bilgisayar oyunu oynamayı başka etkinliklere tercih etme manidar bir farklılık saptanırken; bilgisayar oyununu hayalinde yaşatma ve gerçek hayatıyla ilişkilendirme ve bilgisayar oyunu oynamaktan dolayı görevleri aksatma faktöründe manidar farklılık bulunmamıştır. Bu durum örneklem grubunun sınıf düzeyi aralıklarının yapılan araştırmalarda farklı olmasından kaynaklanabileceği sonucunu düşündürmektedir. 8. sınıf öğrencilerinin ergenlik döneminin de etkisiyle özellikle akademik başarı hedefi olmayan öğrencilerde sosyal medya ve çevrimiçi oyunlara olan bağımlılı̆ı artırdığı; bunun sonucunda da 8. sınıf öğrencilerinin 7. sınıflara göre bilgisayar oyunu 
oynamaktan dolayı; kişisel, ailevi ve diğer görevlerini daha çok aksattıkları ya da sadece ders çalışmaya adapte olduklarından ötürü kendilerini bu konuda suçlu hissettikleri düşünülebilir.

Araştırmada, öğrencilerin ailelerin gelir düzeylerine göre bilgisayar oyun bağımlılık düzeyleri arasında tüm alt faktörler ve tüm maddelerin yer aldığı toplam bağımlılıkta manidar farklılık bulunmamıştır. Bu bulgu Solak (2012) ve Güllü ve diğerleri (2012) yaptıkları çalışmalardaki bulgular ile örtüşmektedir. Bu çalışmanın aksine Horzum (2011) araştırmasında aile gelir düzeyine göre manidar farklılık bulunmuştur. Bu sonuca göre aile gelir düzeyinin çocukların bilgisayar oyunu bağımlılığı davranışları üzerinde önemli bir etkisinin olmadığı söylenebilir. Aynı zamanda öğrencilerin internet erişimlerinin internet kafeler, akıllı telefonlar vb. gibi birçok farklı kaynaktan sağlamalarının etkisi olduğunu düşündürmektedir.

Araştırmada, kişisel bilgisayar sahibi olan öğrencilerin oyun oynamayı bırakamama, oyunu gerçek hayatıyla ilişkilendirme, oyunu oynamaktan dolayı görevleri aksatma, oyun oynamayı başka etkinliklere tercih etme ve toplam oyun bağımlılı̆̆ düzeylerinin bilgisayar sahibi olmayan bulunmayan öğrencilerle arasında manidar farklılık olduğu saptanmıştır. Bu bulgu Şahin ve Tuğrul (2012), Güllü ve diğerleri (2012) yaptıkları araştırma ile örtüşmektedir. Benzer şekilde akıllı telefon sahibi olan öğrencilerin oyun oynamayı bırakamama, oyunu gerçek hayatıyla ilişkilendirme, oyunu oynamaktan dolayı görevleri aksatma, oyun oynamayı başka etkinliklere tercih etme ve toplam oyun bağımlılığı düzeylerinin akıllı telefon sahibi olmayan öğrencilerle arasında manidar farklılık olduğu saptanmıştır. Bu sonucun teknolojideki gelişmelere bağlı olarak bilgisayar oyunların artan oranda akıllı telefonlar üzerinde oynanmasından kaynaklandığı düşünülmektedir. Bu bulgunun ayrıca ele alınıp sosyal değişim bağlamında incelenmesi önemli görülmektedir. Her ne kadar bu çalışmanın aksine bilgisayar sahibi olmanın bilgisayar oyun bağımlılığında önemli bir etken olmadığı sonucuna ulaşan bir çalışmaya rastlansa da (Gökçearslan ve Durakoğlu, 2014) eldeki örnek grubu için bilgisayara ve akıllı telefona daha kolay ulaşabilen öğrencilerin bağımlılık düzeylerinin yüksek olması kayda değer ve üzerinde araştırılması gereken bir bulgu niteliği taşımaktadır.

Araştırma sonuçlarına göre bilgisayar oyunu bağımlıı̆̆ ile bireysel ve sosyal sorumluluk toplam puanları arasında negatif yönlü anlamlı ve zayıf bir ilişki olduğu saptanmıştır. Ayrıca bilgisayar oyun bağımlılığının, bireysel ve sosyal sorumluluk davranışlarını \% 5'in altında yordadığı bulunmuştur. Bu sonuçlara göre çocukların bilgisayar oyunları oynarken; kişisel, ailevi ve sosyal sorumluluklarını yüksek düzeyde aksatmadıkları söylenebilir. Bunda ailelerin çocuklarına süre kısıtlaması koyması ve tatillerde bilgisayar oyunu oynamasına izin vermesinin etkili olduğu çıkarımında bulunulabilir. Literatür incelendiğinde bu araştırmaya benzer bir çalışmaya rastlanmasa da bilgisayar oyun bağımlılı̆̆ı ile farklı değişkenler arasındaki ilişkinin araştırıldığı görülmüştür. Örneğin Bilgin (2015) ortaokul öğrencilerinin bilgisayar oyun bağımlılık düzeyleri ile iletişim becerileri arasındaki ilişkiyi incelediği çalışmasında bilgisayar oyun bağımlılığı ile iletişim becerileri arasındaki korelasyonun negatif yönlü ve anlamlı olduğu ve bilgisayar oyun bağımlıı̆̆ının iletişim beceri puanlarını yordama gücünün \% 6 olduğunu ortaya koymuştur. Çakır ve Akman (2017) 5, 6 ve 7.sınıf öğrencilerinin bilgisayar oyun bağımlılıkları ile kitap okuma alışkanlıkları arasındaki ilişkiyi incelemiş ve istatistiksel olarak negatif yönde düşük fakat anlamlı bir ilişki olduğunu saptamıştır. Öncel ve Tekin (2019)'de ortaokul öğrencilerinin bilgisayar oyun bağımlılıklarıyla yalnızlık durumları arasındaki ilişkiyi incelemiş ve orta düzeyde negatif bir ilişki saptanmıştır. Yapılan bu tür çalışmalar bilgisayar oyun bağımlıı̆̆ının az da olsa öğrencilerin psikolojik ve duyuşsal davranışlarını etkilediğini göstermektedir.

\section{SONUÇ VE ÖNERILER}

Araştırmanın sonuçlarına göre bilgisayar oyunu bağımlılı̆ının çocuklar üzerinde önemli bir faktör olduğu görülmektedir. Günümüzde mobil ortamda, kişisel bilgisayarlarda ve çevrimiçi bütün cihazlarda kolayca erişilebilen bilgisayar oyunlar kontrollü bir şekilde oynanmadığında istenmeyen sonuçlara yol açabilmektedir. Bilgisayar oyunları bağımlılık düzeyinde bağımlılı̆̆ı çocukların oyun oynamaktan vazgeçememe ve engellendiğinde rahatsız olma, bilgisayar oyununu hayalinde yaşatma ve gerçek hayatıyla ilişkilendirme, oyunu oynamaktan dolayı kişisel ve ailevi ve okula ilişkin görevlerini aksatması ve oyun oynamayı başka etkinliklere tercih etmesi gibi sonuçlar ortaya çıkarmaktadır. Uzun süre bilgisayar oyunu oynamaktan kaynaklanan fiziksel rahatsızlıklar, psikolojik problemler, yalnızlık, sosyal fobi gibi problemler çocuğun denetimsiz kalmasıyla oyun bağımlısı olmasının sonucunda yaşanabilmektedir. Özellikle sınav stresi yaşayan 8.sınıfların 7.sınıflara oranla kendilerini oyun oynarken daha rahatsız hissettiklerine dair bulgu bu konuda ailelerin ve öğretmenlerin öğrenciler üzerinde yarattığı etkiden kaynaklandığını düşündürmektedir. Bu açıdan okulların sadece geleceğimizin teminatı olan çocukları değil, aileleri de işin bir parçası haline getirip teknolojinin doğru ve bilinçli kullanımı konusunda özendirici çalışmalar yapması önemli görülmektedir.

Bu çalışmada bilgisayar oyun bağımlılığı kişinin zihinsel faaliyetlerini oyun üzerine odaklanmasıyla belirginleşen oyun fikrinin bireysel ve sosyal anlamda yerine getirmesi gereken görev ve sorumlulukları aksatmaya başlaması ile ifade edilen bağımlığın (APA,2013) ilk fazı olan sorumluk davranışı ile ilişkilendirilmiştir. Eğitim öğretim durumu açısından ise sorumluluk 2017-2018 yıllarında yenilenen ve öğretim programlarının temel odak noktasını oluşturan değer kazanımları incelendiğinde öğrencilere kazandırılması gereken kök değerler arasında yerini almaktadır. Çocukların teknolojiyle tanışma yaşının giderek düştüğü bilgisayar çağda sorumluluk anlayışı kazandırılan öğrencilerin bilgisayar, video oyunları gibi bilgisayar bağımlılıklarının önlenmesinde, azaltılmasında etkili olabileceği düşüncesiyle bu çalışma gerçekleştirilmiştir. Farklı yaş ve örneklem grupları ile yapılacak çalışmalar için araştırmacılara bilgisayar oyun bağımlıı̆̆ı, akıllı telefon bağımlılı̆̆ı, iletişim becerileri, sosyal beceriler vb. gibi farklı değişkenlere ilişkin nitel ve boylamsal araştırma yapmaları önerilebilir.

| Kastamonu Eğitim Dergisi, 2020, Vol. 28, No. 61 


\section{KAYNAKÇA}

Akbaş, O. (2004). Türk milli eğitim sisteminin duyuşsal amaçlarının (değerlerinin) ilköğretim ı. kademedeki gerçekleşme derecesinin değerlendirilmesi. Yayımlanmamış doktora tezi, Gazi Üniversitesi Eğitim Bilimleri Enstitüsü, Ankara.

Aktepe, V., \& Tahiroğlu, M. (2016). Değerler eğitimi yaklaşımları ve etkinlik örnekleri. The Journal of Academic Social Science Studies, 42, 361384.

Akto, A., Akto, A., \& Akto, S. (2017). Okul öncesi değerler eğitiminde kullanılan yöntem ve teknikler (nitel bir araştırma). E-Şarkiyat ilmi Araştırmaları Dergisi/Journal of Oriental Scientific Research (JOSR), 9(2), 1074-1095.

American Psychiatric Association. (2013). Diagnostic and statistical manual of mental disorders (DSM-5 $\left.{ }^{\circledR}\right)$, Retrieved from https://www.dsm5.org/Documents/Internet\%20Ga ming\%20Disorder\%20Fact\%20Sheet.pdf.

Anderson, C.A., Gentile, D.A., \& Buckley, K. (2007). Violent video game effects on children and adolescents: theory, research, and public policy. New York: Oxford University Press.

Ayas, T., Çakır, Ö., \& Horzum, M.B. (2011). Ergenler İçin bilgisayar bağımlılığı ölçeği. Kastamonu Eğitim Dergisi, 19(2), $439-448$.

Bayraktar G., Tozoğlu E., Gülbahçe Ö., Öztürk M. E., \& Gülbahçe A. (2016). Üniversite öğrencilerinin bireysel sosyal sorumluluk düzeylerinin spor ve farklı değişkenler açısından incelenmesi. International Refereed Academic Journal of Sports, Health and Medical Sciences,18, 77-88.

Bilgin, H. C. (2015). Ortaokul öğrencilerinin bilgisayar oyun bağımlılık düzeyleri ile iletişim becerileri arasındaki ilişkinin incelenmesi. (Yayınlanmamış yüksek lisans tezi). Pamukkale Üniversitesi Eğitim Bilimleri Enstitüsü, Denizli.

Buğdaycı, S. (2019). Examining personal and social responsibility levels of secondary school students, Universal Journal of Educational Research, 7(1): 206-210.

Can, A. (2018). SPSS ile bilimsel araştırma sürecinde nicel veri analizi. (6. baskı) Ankara: Pegem Akademi

Çakır, R., \& Akman, E. (2017, Mayıs). Ortaokul öğrencilerinin bilgisayar oyun bağımlılıkları ile kitap okuma alışkanlıkları arasındaki ilişkinin incelenmesi, 11. Uluslarası bilgi teknolojileri sempozyumunda sunulmuş bildiri, İnönü Üniversitesi, Malatya.

Dilmaç, B. (2002). Insanca değerler eğitimi. Ankara: Nobel Yayınları.

Ekşi, H., \& Katılmış, A. (2016). Uygulama örnekleriyle değerler eğitimi. Ankara: Nobel Yayıncılık.

Filiz, B., \& Demirhan, G. (2015). Bireysel ve sosyal sorumluluk ölçeği'nin türk diline uyarlanma çalışması. Spor Bilimleri Dergisi, 26(2), 51-64.

Gentile, D. (2009). Pathological video-game use among youth ages 8 to 18: a national study. Psychological Science, 20(5), 594-602.

Gökçearslan, Ş., \& Durakoğlu, A. (2014 ). Ortaokul öğrencilerinin bilgisayar oyunu bağımlılık düzeylerinin çeşitli değişkenlere göre incelenmesi. Ziya Gökalp Eğitim Fakültesi Dergisi, 23, 419-35.

Güllü, M., Arslan C., Dündar A., \& Murathan, F. (2012). Illköğretim öğrencilerinin bilgisayar oyun bağımlılıklarının incelenmesi. ADYÜ Sosyal Bilimler Enstitüsü Dergisi, 9, 89-100.

Halstead, J.M., \&Taylor, M.J. (2000). Learning and teaching about values : A Review of Recent Research. Cambridge Journal of Education. 30 (2),169-202.

Horzum, M. B. (2011). İlköğretim öğrencilerinin bilgisayar oyunu bağımlılık düzeylerinin çeşitli değişkenlere göre incelenmesi. Eğitim ve Bilim, 36(159), 56-68.

Horzum, M. B., Ayas, T., \& Balta, Ö. Ç. (2016). Çocuklar için bilgisayar oyun bağımlılığı ölçeği. Türk Psikolojik Danışma ve Rehberlik Dergisi, 3(30), 76-88.

Irmak, A. Y., \& Erdoğan, S. (2015). Bilgisayar oyun bağımlılığı ölçeği türkçe formunun geçerliği ve güvenilirliği. Anadolu Psikiyatri Dergisi, 16(1), $10-18$.

Irmak, A. Y., \& Erdoğan, S. (2016). Ergen ve genç erişkinlerde bilgisayar oyun bağımlılığı: güncel bir bakış. türk psikiyatri dergisi, 27(2), 128-37.

Karaca, S., Gök, C., Kalay, E., Başbuğ, M., Hekim, M., Onan, N., \& Ünsal Barlas, G. (2016). Ortaokul öğrencilerinde bilgisayar oyun bağımlılığı ve sosyal anksiyetenin incelenmesi. Clinical and Experimental Health Sciences, 6 (1), 14-19.

Karasar, N. (2018). Bilimsel araştırma yöntemi. Ankara: Nobel Yayınları.

Keser H., \& Esgi N.(2012). An analysis of self-perceptions of elementary school students in terms of computer game addiction. Procedia Social and Behavioral Sciences, 46, 247-251.

Keskin, Y. (2016). Değer sınıflaması üzerine aksiyonel bir deneme. Journal of Turkish Studies, 11, 1485-1485.

Kuzu, O., Akbulut, İ., \& Sivacı, S. Y. (2018, Kasım). Bilgisayar oyun bağımlılı̆ı ile teknoloji okuryazarlığı arasındaki ilişki, I. uluslararası multidisipliner bilgisayar bağımlılık kongresinde sunulmuş bildiri, Milli Eğitim Bakanlığı, Aydın.

Mustafaoğlu, R., Zirek, E., Yasacı, Z., \& Razak Özdinçler, A. (2018). Bilgisayar teknoloji kullanımının çocukların gelişimi ve sağlığı üzerine olumsuz etkileri. Addicta: The Turkish Journal on Addiction, 5, 227-247.

Müller, K. W., Janikian, M., Dreier, M., Wölfling, K., Beutel, M. E., Tzavara, C., ... \& Tsitsika, A. (2015). Regular gaming behavior and internet gaming disorder in European adolescents: results from a cross-national representative survey of prevalence, predictors, and psychopatho-logical correlates. European Child \& Adolescent Psychiatry, 24(5), 565-574.

Öncel, M., \& Tekin, A. (2015). Ortaokul öğrencilerinin bilgisayar oyun bağımlılığı ve yalnızlık durumlarının incelenmesi. Inönü Üniversitesi Eğitim Bilimleri Enstitüsü Dergisi, 2(4), 7-17.

Öncül, R. (2000). Eğitim ve eğitim bilimleri sözlüğ̈̈. İstanbul: MEB Yayınları.

Özdemir, M., \& İdi Tulumcu, F . (2017). Değerler eğitiminde edebi eserlerden yararlanma: Fatma Aliye'nin muhadarat romanı örneği. Sakarya University Journal of Education, 7(4), 720-729. 
Parlar, H., \& Cansoy, Ramazan. (2017). Öğretmen adaylarının öğretmenlik mesleğine yönelik tutumlarının bir yordayıcısı olarak bireysel değerler. Atatürk Eğitim Fakültesi Eğitim Bilimleri Dergisi, 44. 125-142.

Rokeach, M. (1973). The nature of human values. New York: Free press.

Sağlık Bakanlığı. (2019). Bilgisayar oyun bağımlılığı çalıştayı sona erdi. https://www.saglik.gov.tr/TR,50180/bilgisayar-oyun-bagimliligi-calistayisona-erdi.html

Solak, M. Ş. (2012). Ortaöğretim öğrencilerinin bilgisayar oyunu tutumları ile saldırganlık ve yalnızlık eğilimleri arasındaki ilişki. Marmara Üniversitesi Sosyal Bilimler Enstitüsü, Yayımlanmamış Yüksek Lisans Tezi, İstanbul.

Suh, B. K., \& Traiger, J. (1999). Teaching values through elementary social studies and literature curricula. Education. 119 (4), 723-726.

Şahin, C., \& Tuğrul, V. M. (2012). ilköğretim öğrencilerinin bilgisayar oyunu bağımlılık düzeylerinin incelenmesi. Journal Of World Of Turks, 4, 115130.

Tazegül, Ü. (2014). Sporun kişilik üzerindeki etkisinin araştırılması. The Journal of Academic Social Science Studies International Journal of Social Science, 25, 537-544.

TDK.[Türk Dil Kurumu]. (2019). www.tdk.gov.tr

TTKB. [Talim Terbiye Kurulu Başkanlığı]. (2017). Müfredatta Yenileme ve Değişiklik Üzerine. Ankara.

Ulum, H. (2016). Çocuklarda bilgisayar oyunu bağımılı̆̆ı ile duygu ayarlayabilme arasındaki ilişkinin incelenmesi. Çağ Üniversitesi Sosyal Bilimler Enstitüsü, Yayınlanmamış Yüksek Lisans Tezi, Mersin.

Van Rooij, A. J., Schoenmakers, T. M., Vermulst, A. A., Van Den Eijnden, R. J., \& Van De Mheen, D. (2011). Online video game addiction: identification of addicted adolescent gamers. Addiction, 106(1), 205-212.

World Health Organization. (2018). Gaming disorder. Retrieved from https://www.who.int/features/qa/gaining-disorder/en (Date: 06.09.2019).

Yazıcı, D. (2006). Değerler eğitimi'ne genel bir bakış. Türklük Bilimi Araştırmaları, 19, 499-522. 